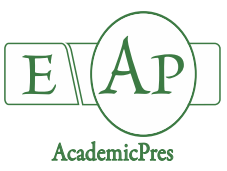

Tavangar A et al. (2021)

Notulae Botanicae Horti Agrobotanici Cluj-Napoca

Volume 49, Issue 2, Article number 12038

DOI: $10.15835 /$ nbha 49212038

Research Article

\title{
Effect of salinity and drought stress on morphological and biochemical properties of two Iranian fenugreek (Trigonella foenum-graecum) populations
}

\author{
Afsaneh TAVANGAR ${ }^{1}$, Leila KARAMI ${ }^{1,2}$, Mohammad HEDAYAT ${ }^{1}$, \\ Gholamreza ABDI ${ }^{2 *}$
}
${ }^{1}$ Persian Gulf University, Bushehr, Department of Horticulture, College of Agriculture, 7516913817, Iran; a.f.tavangar@gmail.com; leila.karami@pgu.ac.ir;m.hedayat@pgu.ac.ir
${ }^{2}$ Persian Gulf University, Department of Biotechnology, Persian Gulf Research Institute, Bushehr, 7516913817, Iran; abdi@pgu.ac.ir ("correspondingauthor)

\begin{abstract}
In this study, micro propagation of two Iranian fenugreek populations and their morphological and biochemical responses to salinity and drought stresses in in vitro culture condition were conducted using factorial experiment in a completely randomized design in three replications. Different explant type (terminal bud, cotyledon and epicotyledon explant) were cultured in MS medium contain different concentration of plant growth regulators such as kin $(0,0.5$ and $1 \mathrm{mg} / \mathrm{l})$ and 2,4-D (0.5, 1 and $2 \mathrm{mg} / \mathrm{l})$. Murashige and Skoog (MS) medium supplemented with $1 \mathrm{mg} / \mathrm{l}$ kinetin and $2 \mathrm{mg} / 12,4-\mathrm{D}$ showed the highest callus proliferation rate per explants in both populations. The highest amount of callus volume was obtained from the explants of the terminal bud. Proliferated calli from terminal bud explant were green and yellowish, from cotyledon were yellowish to white with soft texture, and the cotyledons were greenish and compact. The results of salinity stresses with different concentrations of sodium chloride $(0,70$ and $120 \mathrm{mM})$ and drought stress with polyethylene glycol $(0,5$ and $10 \%)$ showed that both stresses decreased callus growth and increased total protein, proline, catalase, peroxidase and trigonelin content in both populations. Trigonelin measurement showed that 'Borazjan' papulation had higher trigonelin content, in vitro, than 'Ardestan' papulation.
\end{abstract}

Keywords: callus induction; drought stress; fenugreek; salinity stress; trigonelin

\section{Introduction}

One of the severely detrimental factors to the growth and yield of the all crops around the world is drought and salinity stress. Also, all plants during ontogeny, have different interaction with its surrounding environment; they come in contact with different abiotic components like water, light, temperature, soil and chemicals (Anjum et al., 2011). Trigonella foecum-graecum L. (fenugreek) belongs to the Leguminosae family (Rezaian et al., 2011) it is used as forage, vegetable, medicinal plant and also for some preservative purposes. Fenugreek root, seed, and shoot are an important metabolite source such as trigonelin, diosgenin, neotycogenin and yamogenin and have high demand in the steroid industry (Esmaeil and Rezaeinodehi, 2014). Trigonline 
or $\mathrm{N}$-methyl nicotinic acid is a secondary metabolite derived from pyridine nucleotides (Mehrafarin et al., 2010). Drought and salinity stress in plant can alter various physiological activities, cause oxidative damages in various cellular components of the cell, interrupt in membranes activity, impact on photosynthetic activity, nutrient imbalance, decrease or increase in reactive oxygen species (ROS) detoxification system, damage on biomolecules such as membrane lipid, proteins, enzymes and nucleic acid (Abeles and Biles,1991). The osmolytes accumulation such as glycine, betaine, proline, and trigonellin in cell is known to protect organisms against abiotic stresses via osmoregulation or osmoprotection. Fenugreek is containing trigonelline that plays an osmoregulatory role in abiotic stress. Osmoregulatory properties of trigonelline revealed that fenugreek is a tolerant plant to environmental stress by increasing the endogenous melatonin and trigonelline, as well as the general physiological responses (Tramontano and Jouve, 1997). Plant tissue culture is a valuable biotechnological tool for plant research in different field such as cell signalling, gene manipulation, cell and plant physiology, morphogenesis, deep understanding the molecular biology and crop improvement using biotechnology (Khawar et al., 2004). Here we tried to establish a high-performance callus induction and growth method to facilitate the basic research and genetic breeding of this important fenugreek species. Also, this study aimed to study the effect of salinity and drought stress on morphological, biochemical and quantitative and qualitative properties of secondary fenugreek metabolites due to the nutritional and medicinal value of fenugreek in Bushehr province in tissue culture system was performed.

\section{Materials and Methods}

This study was conducted in College of Agriculture and Natural Resources of Persian Gulf University. In this study, two genotypes of fenugreek ('Ardestan' and 'Borazjani') were used. Seeds washed first under running tap water at least $30 \mathrm{~min}$, surface sterilized in $70 \%$ alcohol for $1 \mathrm{~min}$, rinsed twice with sterile distilled water, immersed in beaker containing a sodium hypochlorite for 20 minutes and then immersed three times in sterile water for 5 minutes. After surface washing, the seeds were cultured in MS medium with paper supplement. For callus regeneration, 2-week-old buds, cotyledons and epicotyledons explants were cultured in MS medium containing 2,4-D (0.5, 1 and $2 \mathrm{mg} / \mathrm{l})$ and kin $(0,0.5$ and $1 \mathrm{mg} / \mathrm{l})$. Cultures were kept at 25 2 ${ }^{\circ} \mathrm{C}, 16 \mathrm{~h}$ of illumination $(2000 \mathrm{~L}$ of light illumination) and $8 \mathrm{~h}$ of darkness in the growth chamber. After 30 days, morphological traits were recorded. To investigate the effect of salinity $(\mathrm{NaCl}: 0,70$ and $120 \mathrm{mM})$ and drought stress (PEG 6000: 0, 5 and 10\%) on callus, the best callus regeneration medium (MS $+2 \mathrm{mg} / 12,4-\mathrm{D}$ +1 Kin) was prepared. After subculture of calli originated from the terminal-bud explants, the small pieces of callus were transferred to the selected culture medium for salinity and drought stress experiment. After 30 days biochemical traits were measured. Two-week-old seedling buds were used in field conditions to compare trigonelin levels with in vitro conditions.

\section{Determination of biochemical properties}

Protein extraction and measurement

One gram of callus was abraded with $3 \mathrm{~mL}$ of $25 \mathrm{mM}$ tris, acid hydrochloric acid buffer ( $\mathrm{pH} 6.8$ ) and $3 \%$ polyvinylpyrrolidone (PVPP) in mortar and then incubated at $4{ }^{\circ} \mathrm{C}$ for $13,000 \mathrm{rpm}$, centrifuge for one hour. The upper phase containing total protein was separated and the total protein content was measured by Bradford method using BSA bovine serum albumin as standard curve with spectrophotometer at $595 \mathrm{~nm}$ (Bradford, 1976).

$\underline{\text { Proline }}$

Proline content of treated plant was determined as described by Bates et al. (1973). After the analyses, following equation: (g proline in extract $/ 115.5) \mathrm{g}^{-1}$ sample $=\mathrm{mol} \mathrm{g}^{-1} \mathrm{FW}$ ) were used for calculation the proline concentration from a standard curve. 
$\underline{\text { Enzyme assays }}$

At the end of experiment, leaves were collected and frozen in liquid nitrogen and stored at $280^{\circ} \mathrm{C}$ before enzyme extraction. ROS scavenger enzymes were extracted as described by Zhang and Kirkham (1996) with some modifications. All operations were carried out at $4{ }^{\circ} \mathrm{C}$. Intact leaves were ground using mortar and pestle under liquid nitrogen in cold $50 \mathrm{mM}$ sodium phosphate, $\mathrm{pH} 7.5$, containing $250 \mathrm{mM}$ sucrose, $10 \mathrm{mM} \mathrm{KCl,}$ $\mathrm{mM} \mathrm{MgCl} 2,1.0 \mathrm{mM}$ EDTA, $0.5 \mathrm{mM} 0.1 \mathrm{mM}$ dithiothreitol, phenylmethylsulfonyl fluoride, and $1 \%$ (w/v) polyvinylpolypyrrolidone in a $6: 1$ proportion $(\mathrm{w} / \mathrm{v})$. The homogenate was then filtered and centrifuged at $25,000 \mathrm{~g}$ for $20 \mathrm{~min}$ at $4^{\circ} \mathrm{C}$. Then solid ammonium sulfate (NH4)2SO4 added to the supernatant to make up $80 \%$ saturated solution and allowed to stir gently for several hours at $4{ }^{\circ} \mathrm{C}$. After centrifugation $(28,000 \mathrm{~g}$ for $45 \mathrm{~min}$ at $\left.4{ }^{\circ} \mathrm{C}\right)$, pellets, were resuspended in a small volume of $50 \mathrm{mM}$ sodium phosphate $(\mathrm{pH} 7.5)$ and used for enzyme assays. The activity of peroxidase was measured by determining the increase in absorbance at 470 $\mathrm{nm}$ for 2 min using procedure of Hildebrand et al. (1986) and Heng-Moss et al. (2004). One millilitre reaction mixture contained $2 \mu \mathrm{l}$ of $30 \%$ hydrogen peroxide $60 \mu \mathrm{l}$ of $18 \mathrm{mM}$ guaiacol, $20 \mu \mathrm{l}$ of $200 \mathrm{mM}$ HEPES (pH 7.0), $117 \mu \mathrm{l}$ of distilled water, and $1 \mu \mathrm{l}$ of callus extract. Catalase activities $\left(\varepsilon \mathrm{H}_{2} \mathrm{O}_{2}=39.4 \mathrm{mM}^{-1} \mathrm{~cm}^{-1}\right)$ were assayed spectrophotometrically according to Zhang and Kirkham (1996) method by monitoring the change in A240 due to the decreased absorption of $\mathrm{H}_{2} \mathrm{O}_{2}$. The reaction mixture contained enzyme extract, $50 \mathrm{mMNa}-\mathrm{P}, \mathrm{pH}$ 7.0, and $15 \mathrm{mM} \mathrm{H}_{2} \mathrm{O}_{2}$ (in $1 \mathrm{~mL}$ final volume). The reaction was initiated by addition of $\mathrm{H}_{2} \mathrm{O}_{2}$. Catalase activity was determined according to the method used by Aebi (1984) in which the disappearance $\mathrm{H}_{2} \mathrm{O}_{2}$ in a reaction mixture containing $0.3 \mathrm{~mL} 3 \% \mathrm{H}_{2} \mathrm{O}_{2}, 2.5 \mathrm{~mL}$ of $0.05 \mathrm{M}$ phosphate buffer ( $\mathrm{pH} 7$ ), and $2.5 \mathrm{~mL}$ of plant extract is monitored by the decrease in absorbance at $240 \mathrm{~nm}$.

Trigonelin measurement

Stress-induced calli and two-week-old seedlings of a field grown plant of both papulations were sent to the Karaj University (Jihad Institute for Medicinal Plants) for trigonelin measurement. Samples ( $0.2 \mathrm{~g}$ of dried calluses) were powdered and sonicated with $10 \mathrm{ml}$ of methanol by ultrasonic bath for half an hour. The mixture was then centrifuged ( $5000 \mathrm{rpm})$ for 10 minutes. The supernatant was evaporated and the residue was dissolved in $2 \mathrm{ml}$ of methanol and stored in a refrigerator $\left(4^{\circ} \mathrm{C}\right)$. Determination of trigonelin had done by Agilent 1260 Infinity series HPLC (Agilent Technologies, Santa Clara, CA) equipment and column (C18, $25 \mathrm{Cm} \times 4.6 \mathrm{~mm}$ ID, $5 \mu \mathrm{m})$. The mobile phase consisted of the ratio of acetonitrile: water, 10:90, respectively. The elution time and flow rates were $6 \mathrm{~min}$ and $1 \mathrm{ml} / \mathrm{min}$, respectively. The absorbance of trigonelin detected at $263 \mathrm{~nm}$. For detection of trigonelin, the standard solution (Sigma) was used. The Open Lab software was used to peak integration (Rongjie et al., 2010).

\section{Statistical analysis}

This experiment was performed in factorial arrangement based a completely randomized design with 3 replicates. Data were analysed by SAS software, and new Duncan multiple range test $(\mathrm{p}<0.05)$ was used for determining the differences among treatments.

\section{Results and Discussion}

\section{Callus regeneration rate}

According to the results of analysis of variance analysis, a highly significant effect of the explant type, papulation type and the PGRs on the callus regeneration was observed. There was no significant difference between the PGRs and papulation on callus regeneration (Table 1). 
Table 1. Analysis of variance (ANOVA) of explant type, papulation type and the PGRs and their interactions on the callus regeneration of fenugreek

\begin{tabular}{|c|c|c|}
\hline SOV & $d f$ & Mean Squares \\
\hline Population & 1 & $126 / 23^{* *}$ \\
\hline Explant type & 2 & $133 / 52^{*}$ \\
\hline Plant growth regulator & 8 & $71 / 14^{* *}$ \\
\hline Explant type $\times$ Population & 2 & $123 / 97^{* *}$ \\
\hline Explant type $\times$ growth regulator & 16 & $5 / 20^{* *}$ \\
\hline Population $\times$ plant growth regulator & 8 & $0 / 67^{\mathrm{ns}}$ \\
\hline Population $\times$ Explant type $\times$ Plant growth regulator & 16 & $3 / 38^{* *}$ \\
\hline Error & 108 & $0 / 85$ \\
\hline Total & 161 & \\
\hline $\mathrm{CV}(\%)$ & & 9.08 \\
\hline
\end{tabular}

The most abundant callus proliferation rate was observed on MS supplemented with $1 \mathrm{mg} \cdot \mathrm{L}^{-1} 2,4-\mathrm{D}$, and $1 \mathrm{mg} \cdot \mathrm{L}^{-1} \mathrm{Kin}$ in 'Ardestan' population as well as on MS media supplemented with $2 \mathrm{mg} \cdot \mathrm{L}^{-1} 2$, 4-D, and $1 \mathrm{mg} \cdot \mathrm{L}^{-1} \mathrm{Kin}$ in 'Borazjan' population. The lowest number of callus proliferation rate was produced by epicotyl explants cultured on media supplemented with different concentration of 2,4-D without kin in both populations. Also, the same results were obtained in case of using the terminal bud explant of 'Borazjan' population (Table 2).

Table 2. Effect of explant type and different concentration of Kin and 2,4-D on callus regeneration in different Trigonella foenum-graecum populations

\begin{tabular}{|c|c|c|c|c|c|c|c|}
\hline \multirow{2}{*}{\multicolumn{2}{|c|}{ PGRs (mg/l) }} & \multicolumn{6}{|c|}{ Population } \\
\hline & & \multicolumn{3}{|c|}{ 'Ardestan' } & \multicolumn{3}{|c|}{ 'Borazjan' } \\
\hline Kin & $2,4-\mathrm{D}$ & Terminal bud & Epicotyledon & Cotyledon & Terminal bud & Epicotyledon & Cotyledon \\
\hline 0 & $0.5^{*}$ & $10 / 00^{\mathrm{h}-\mathrm{k}}$ & $4 / 67^{q}$ & $7 / 33^{\mathrm{m}-\mathrm{p}}$ & $5 / 83^{p q}$ & $5 / 17^{q}$ & $7 / 50^{1-p}$ \\
\hline 0 & 1 & $10 / 50^{g-j}$ & $6 / 00^{\text {opq }}$ & $7 / 83^{\operatorname{lmn}}$ & $7 / 33^{\mathrm{m}-\mathrm{p}}$ & $5 / 33^{q}$ & $7 / 67^{1-o}$ \\
\hline 0 & 2 & $12 / 50^{\text {ef }}$ & $6 / 17^{n-q}$ & $9 / 17^{\mathrm{i}-\mathrm{m}}$ & $8 / 67^{j-m}$ & $4 / 33^{q}$ & $9 / 33^{i-1}$ \\
\hline $0 / 5$ & $0 / 5$ & $12 / 00^{\text {efg }}$ & $7 / 67^{1-o}$ & $10 / 00^{h-k}$ & $7 / 50^{1-p}$ & $8 / 00^{\operatorname{lm}}$ & $9 / 00^{j-m}$ \\
\hline $0 / 5$ & 1 & $13 / 00^{\mathrm{de}}$ & $9 / 17^{\mathrm{i}-\mathrm{m}}$ & $11 / 83^{\text {efg }}$ & $8 / 00^{\operatorname{lm}}$ & $10 / 50^{g-j}$ & $9 / 17^{\mathrm{i}-\mathrm{m}}$ \\
\hline $0 / 5$ & 2 & $16 / 00^{\mathrm{ab}}$ & $9 / 00^{j-m}$ & $11 / 67^{\mathrm{e}-\mathrm{h}}$ & $9 / 17^{\mathrm{i}-\mathrm{m}}$ & $10 / 33^{g-j}$ & $12 / 50^{\text {ef }}$ \\
\hline 1 & $0 / 5$ & $15 / 67^{b c}$ & $7 / 83^{\operatorname{lmn}}$ & $9 / 17^{\mathrm{i}-\mathrm{m}}$ & $9 / 17^{\mathrm{i}-\mathrm{m}}$ & $9 / 00^{j-m}$ & $8 / 33^{\mathrm{klm}}$ \\
\hline 1 & 1 & $17 / 33^{a}$ & $9 / 00^{j-m}$ & $10 / 00^{h-k}$ & $10 / 00^{h-k}$ & $9 / 17^{\mathrm{i}-\mathrm{m}}$ & $10 / 00^{h-k}$ \\
\hline 1 & 2 & $17 / 00^{\mathrm{ab}}$ & $12 / 00^{\text {efg }}$ & $12 / 50^{\text {ef }}$ & $11 / 00^{f-i}$ & $11 / 00^{\mathrm{f}-\mathrm{i}}$ & $14 / 33^{\text {cd }}$ \\
\hline \multicolumn{2}{|c|}{ Mean } & $13 / 78^{\mathrm{A}}$ & $7 / 94^{D}$ & $9 / 94^{\mathrm{B}}$ & $8 / 52^{\mathrm{C}}$ & $8 / 09^{\mathrm{CD}}$ & $9 / 76^{\mathrm{B}}$ \\
\hline
\end{tabular}

${ }^{*}$ Means in a column followed by the same letter do not differ significantly at $p=0.05$. Mean with uppercase indicate the interaction of papulation and explant type and lowercase indicate the interaction between plant growth regulator, papulation and explant type. Callus regeneration rate was numbered based on the amount of callus apparent volume including very small callus 5, small 10, medium 15, large 20 and very large 25 .

Numerous reports indicate a direct influence of PGRs on the callus induction of different type of explant in fenugreek. Jamshidi et al. (2014) reported that Fenugreek leaf explant in MS medium containing $0.5 \mathrm{mg} / \mathrm{l}$ Kin and $1.5 \mathrm{mg} / \mathrm{l} 2$,4-D had the highest callus growth and weight. Vaezi et al. (2015) also reported the highest callus induction and growth of fenugreek cotyledon explants with MS medium containing $0.5 \mathrm{mg} / \mathrm{l} \mathrm{Kin}$ and $1.5 \mathrm{mg} / \mathrm{l}$ 2,4-D. Khadiga et al. (2014) obtained the highest amount of callus in fenugreek using cotyledon explants in $B_{5}$ medium supplemented with $2 \mathrm{mg} / \mathrm{l}$ 2,4-D. Mohayeb et al. (2013), realized that 2,4-D in combination with Kin ( 2 and $0.5 \mathrm{mg} / \mathrm{L}$ respectively) obtained the highest amount of callus regeneration in hypocotyledon explant. Bashir and Alaf (2016) reported the best combination for producing the highest callus weight in fenugreek plant was $1 \mathrm{mg} / 12,4-\mathrm{D}$ and BA. These findings are consistent with the present study in 
terms of Kin content but differ in 2,4-D concentration. In general, the results of the present work confirmed literature reports regarding the auxins such as 2,4-D to initiate callus formation in many herbaceous species (Taha et al., 2009). Gorel (2001) found that 2,4-D had the highest impact on callus regeneration than other type of the auxins. It seems that the use of auxins in high concentration than cytokinins can increase the callus regeneration rate in fenugreek. In this experiment, different colors and textures of callus were observed according to the explant type. But there was not significant difference between papulation in various hormone treatments. The callus formed was soft and light green colored, compact and yellow green or olive colored, soft, friable and yellowish colored in apical bud, cotyledon and hypocotyl explant respectively.
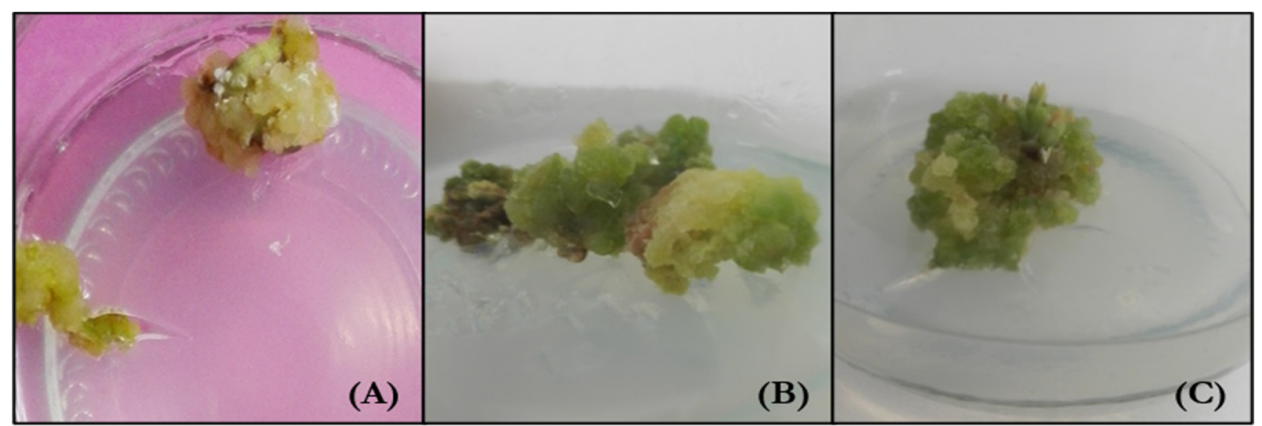

Figure 1. Colors and textures of callus on medium supplemented with different plant growth regulators (A) Soft and friable light green colored in apical bud explant (B) Compact yellow green callus in cotyledon (C) Soft yellowish callus in hypocotyl explant

Table 3. Callus growth performance of different explant of Trigonella foenum-graecum papulations under different PGRs treatments

\begin{tabular}{|c|c|c|c|c|c|c|c|c|c|c|c|c|c|}
\hline \multirow{3}{*}{\multicolumn{2}{|c|}{ PGRs (mg/l) }} & \multicolumn{12}{|c|}{ Population } \\
\hline & & \multicolumn{6}{|c|}{ 'Ardestan' } & \multicolumn{6}{|c|}{ 'Borazjan' } \\
\hline & & \multicolumn{2}{|c|}{ Cotyledon } & \multicolumn{2}{|c|}{ Hypocotyl } & \multicolumn{2}{|c|}{ Apical Bud } & \multicolumn{2}{|c|}{ Cotyledon } & \multicolumn{2}{|c|}{ Hypocotyl } & \multicolumn{2}{|c|}{ Apical Bud } \\
\hline Kin & $2,4-\mathrm{D}$ & Color & Texture & Color & Texture & Color & Texture & Color & Texture & Color & Texture & Color & Texture \\
\hline 0 & $0 / 5$ & + & $\mathrm{F}$ & +++ & $\mathrm{F}$ & ++ & $\mathrm{C}$ & + & $\mathrm{F}$ & +++ & $\mathrm{F}$ & ++ & $\mathrm{C}$ \\
\hline 0 & 1 & + & F & +++ & F & ++ & $\mathrm{C}$ & + & $\mathrm{F}$ & +++ & $\mathrm{F}$ & ++ & $\mathrm{C}$ \\
\hline 0 & 2 & + & $F$ & +++ & $\mathrm{F}$ & ++ & $\mathrm{C}$ & + & $F$ & +++ & $F$ & ++ & $\mathrm{C}$ \\
\hline $0 / 5$ & $0 / 5$ & + & F & +++ & $\mathrm{F}$ & ++ & $\mathrm{C}$ & + & $\mathrm{F}$ & +++ & $\mathrm{F}$ & ++ & $\mathrm{C}$ \\
\hline $0 / 5$ & 1 & + & $\mathrm{F}$ & +++ & $\mathrm{F}$ & ++ & $\mathrm{C}$ & + & $\mathrm{F}$ & +++ & $\mathrm{F}$ & ++ & $\mathrm{C}$ \\
\hline $0 / 5$ & 2 & + & $F$ & +++ & F & ++ & $\mathrm{C}$ & + & $\mathrm{F}$ & +++ & $\mathrm{F}$ & ++ & $\mathrm{C}$ \\
\hline 1 & $0 / 5$ & + & F & +++ & $\mathrm{F}$ & ++ & $\mathrm{C}$ & + & $\mathrm{F}$ & +++ & $\mathrm{F}$ & ++ & $\mathrm{C}$ \\
\hline 1 & 1 & + & $\mathrm{F}$ & +++ & $\mathrm{F}$ & ++ & $\mathrm{C}$ & + & $\mathrm{F}$ & +++ & $\mathrm{F}$ & ++ & $\mathrm{C}$ \\
\hline 1 & 2 & + & F & +++ & $\mathrm{F}$ & ++ & $\mathrm{C}$ & + & $\mathrm{F}$ & +++ & $\mathrm{F}$ & ++ & $\mathrm{C}$ \\
\hline
\end{tabular}

\section{Salinity and drought stress effects on Trigonella foenum-graecum \\ Drought stress}

In order to evaluate the response to salinity and drought stress of Trigonella foenum-graecum, at the cellular level in different papulations, callus was transferred to MS medium supplemented with 70 and 120 mmol $1^{-1} \mathrm{NaCl}$ and poly ethylene glycol (5 and $10 \%$ PEG). The relative growth rate of callus reached a maximum in the control treatment and at the presence of $\mathrm{NaCl}$, growth was decreased with increasing $\mathrm{NaCl}$ concentrations (70 and $120 \mathrm{mmol} \mathrm{l}^{-1}$ ). Also, no significant difference was observed within examined populations (Table 5). Noobar et al. (2010) reported that salinity stress on four Iranian fenugreek species showed that the fresh and dry weight of species decreased with increasing the salinity concentration. In another study, Kiani and Niknam (2015) reported that with increasing salinity, a remarkable decrease in callus growth was observed in both species of fenugreek. In the study of, as the concentration of sodium chloride increased, callus fresh weight in fenugreek decreased (Asam, 2011). The same results were reported in fenugreek (Zia et 
al., 2010; Nam, 2011; Soheilikhah et al., 2013). The results of these studies are in parallel with our present study. Decreasing the plant growth rate under salinity stress can be due to inhibition of cell division and proliferation or even cell death, water shortage, salt toxicity, nutrient imbalance, and impaired absorption, interfering with normal cellular processes, especially processes involved in energy production such as photosynthesis and respiration (Shibli et al., 2007). The results in the Table 4 showed the impact of drought stress was significant increase in callus growth rate in treated calluses with PEG. The highest callus growth rate was observed in 'Ardestan' population in control treatment which had significant difference with other treatment. Also, with increasing PEG concentration, there was a significant decrease in callus growth in both populations, especially in 'Ardestan' population (Table 4). Kiani and Niknam (2015) reported that by increase in drought (mannitol) a marked decrease in callus growth in both species of fenugreek were observed. The results of these studies are consistent with the present study. Drought stress decreases growth by preventing cell growth and reducing cell division (Anjum et al., 2011). Significance of the effect of callus growth on drought stresses confirms the existence of high genetic diversity among genotypes in terms of the traits evaluated which is in parallel with the report of Farhadi et al. (2014).

Table 4. Impact of salinity and drought stress on different on calli growth rate obtained from 'Ardestan' and 'Borazjan' populations of fenugreek

\begin{tabular}{|l|c|c|c|c|c|c|}
\hline \multirow{2}{*}{ Population } & \multicolumn{3}{|c|}{$\mathrm{NaCl}(\mathrm{mM})$} & \multicolumn{3}{c|}{ PEG (\%) } \\
\cline { 2 - 7 } & 0 & 70 & 120 & 0 & 5 & 10 \\
\hline 'Ardestan' & $22.22^{\mathrm{a}}$ & $16 / 66^{\mathrm{bc}}$ & $13 / 89^{\mathrm{c}}$ & $22 / 22^{\mathrm{a}}$ & $15.00^{\mathrm{bc}}$ & $9.44^{\mathrm{de}}$ \\
\hline 'Borazjan' & $17.77^{\mathrm{b}}$ & $15.00^{\mathrm{bc}}$ & $13 / 89^{\mathrm{c}}$ & $17 / 77^{\mathrm{b}}$ & $12.22^{\mathrm{cd}}$ & $7.77^{\mathrm{e}}$ \\
\hline
\end{tabular}

${ }^{*}$ Means in a column followed by the same letter do not differ significantly at $p=0.05$.

\section{Salinity stress}

Metabolic activity within the callus was determined by measuring the proline content and catalase, peroxidase activity and total protein under salinity stress. Highest protein and proline content were obtained in stressed calli in media contain $70 \mathrm{mmol} \mathrm{l}^{-1} \mathrm{NaCl}$ in 'Borazjan' population. In contrast, highest proline and protein content in 'Ardestan' population was observed in maximum salinity level. Protein and proline content of both stressed calli decreased respective to the control treatment. POX and CAT activities showed statistically significant differences $(\mathrm{P}<0.05)$ between stressed calli and respective control according to the intensity of salinity stress (Table 5). The highest POX and CAT activities was observed in media contain 120 mmol $\mathrm{l}^{-1} \mathrm{NaCl}$ in both populations. However, these values were significantly in 'Ardestan' population $(\mathrm{P}<0.05)$ than their respective controls and 'Borazjan' population. Sarahi Nobar et al. (2010) reported that the protein content of $T$. foenum-graecum, T. aphanoneura and T. tehranica decreased under salinity stress and increased in T. elliptica. But, the proline content in T. tehranica and T. elliptica increased in $70 \mathrm{mmol} \mathrm{NaCl}$. Also, the proline content in calli originated from $T$. foenum-graecum decreased in high concentrations of sodium chloride (120 ppm). Kiani and Nicknam's (2015) study showed that salinity reduced protein in calli of $T$. foenum-graecum and T. aphanoneura compared to control. Proline content of $T$. foenum-graecum was slightly decreased at $120 \mathrm{mM}$ salinity and no significant change was observed in $T$. aphanoneura callus. In the present study, the amount of protein increased with increasing salinity compared to the control. But, in 'Borazjan' population at high salinity level a slight decrease was observed compared to salinity of $70 \mathrm{mM}$. The increase in protein content can be due to the induction of several proteins that are newly developed in response to salinity stress or are present at low concentrations, and when the plants are exposed to salinity, their concentration increases (Hall and Flowers, 1973; Levitt, 2015). In the present study, it seems that for the above-mentioned reasons, the amount of protein increased under salinity stress compared to control.

Proline content under salinity stress was increased compared to the control treatment. Proline content decreased in 'Borazjan' population at $120 \mathrm{mM}$ salinity compared to the $70 \mathrm{mM}$ salinity treatment. Accumulation of compatible solutes in the cytoplasm e.g. proline helps plant to maintain the osmotic balance and reduce the membrane damage. Compatible solutes do not impair normal physiological functions even if 
accumulated at high concentrations (Pandey and Agarwal, 1998; Saneoka, 2004; Hayat et al., 2012). Compatible solutes accumulation in cytosol and in organelles and its osmotic protection and association role with salt tolerance has been reported in higher plants. In the present study, it seems that the amount of proline can be used as a suitable indicator for assessing salt tolerance in fenugreek under in vitro conditions. Therefore, 'Borazjan' can be more resistant to salt stress than 'Ardestan' due to its high proline content. Kiani and Nicknam (2015) reported that catalase and peroxidase activity increased in the callus of two species of fenugreek under salinity stress $(100 \mathrm{mM} \mathrm{NaCl})$. These results are in parallel with the results of the present study. In this study, salinity in both fenugreek papulations increased the catalase and peroxidase activity compared to control treatment. Changes in the activity of antioxidant enzymes are one of the mechanisms that occur in plants to increase the plant tolerance in front of environmental stress. Catalase molecule can convert millions of hydrogen peroxide molecules to water and oxygen blocks free radical chain reactions (Rakmini, 2004) Therefore, it seems that calli were tolerate to this condition by increasing the activity of catalase and peroxidase.

Table 5. Impact of salinity stress on different biochemical parameters in calli obtained from 'Ardestan' and 'Borazjan' populations of fenugreek

\begin{tabular}{|c|c|c|c|c|c|}
\hline Population & $\begin{array}{c}\mathrm{NaCl} \\
(\mathrm{mM})\end{array}$ & $\begin{array}{c}\text { Total protein } \\
(\mathrm{mg} / \mathrm{g} \mathrm{FW})\end{array}$ & $\begin{array}{c}\text { Proline } \\
(\mu \mathrm{mol} / \mathrm{g} \mathrm{FW})\end{array}$ & $\begin{array}{c}\text { CAT }(\mu \mathrm{mol} / \mathrm{min} . \mathrm{mg} \\
\text { protein })\end{array}$ & $\begin{array}{c}\text { POX }(\mu \mathrm{mol} / \\
\text { min.mg protein })\end{array}$ \\
\hline \multirow{3}{*}{ 'Ardestan' } & Control & $17.91^{\mathrm{c}}$ & $3 / .23^{\mathrm{f}}$ & $0.002^{\mathrm{c}}$ & $0.06^{\mathrm{c}}$ \\
\cline { 2 - 6 } & 70 & $18.48^{\mathrm{c}}$ & $4.28^{\mathrm{e}}$ & $0.006^{\mathrm{a}}$ & $0.08^{\mathrm{ab}}$ \\
\cline { 2 - 6 } & 120 & $19.79^{\mathrm{c}}$ & $9.12^{\mathrm{c}}$ & $0.007^{\mathrm{a}}$ & $0.09^{\mathrm{a}}$ \\
\hline \multirow{3}{*}{ 'Borazjan' } & Control & $13.07^{\mathrm{d}}$ & $7.13^{\mathrm{d}}$ & $0.003^{\mathrm{c}}$ & $0.06^{\mathrm{c}}$ \\
\cline { 2 - 6 } & 70 & $35.46^{\mathrm{a}}$ & $13.61^{\mathrm{a}}$ & $0.005^{\mathrm{b}}$ & $0.06^{\mathrm{c}}$ \\
\cline { 2 - 6 } & 120 & $31.69^{\mathrm{b}}$ & $12.63^{\mathrm{b}}$ & $0.006^{\mathrm{ab}}$ & $0.07^{\mathrm{bc}}$ \\
\hline
\end{tabular}

${ }^{*}$ Means in a column followed by the same letter do not differ significantly at $p=0.05$.

Kiani and Niknam (2015) studied two species of fenugreek under drought stress (0, 180- and $275 \mathrm{mM}$ mannitol) and reported that the amount of protein and proline callus increased. In their study, T. foenumgraecum had higher proline content than T. aphanoneura. Navin et al. (2014) reported significant higher proline content than control on calluses from different explants of fenugreek under drought stress at different times and concentrations of mannitol. Similar results were reported by Salma et al. (2016) and Layegh Khoydaki et al. (2010), respectively, by studying different cultivars of Pisum sativum and Salvia leriifolia Benth under drought stress.

In the present study, by increasing drought stress and concentrations of PEG, proline content was increased in both populations compared to control. This proline accumulation under stress protects the cell from its adverse effects by osmotic adjustment of cytosol with that of the vacuole and external environments. Increase in proline content may relate to the decrease the incorporation of proline to proteins, synthesizing the anti-oxidants and enhancing activities of anti-oxidative enzymes or increasing expression of proline biosynthetic enzymes and decreasing proline degradation enzymes activity (Zhang, 1990). The obtained results in this study bring to surface the correlation between proline levels and drought tolerance in calli, obtained from different populations of fenugreek. 
Table 6. Impact of drought stress on different biochemical parameters in calli obtained from 'Ardestan' and 'Borazjan' populations of fenugreek

\begin{tabular}{|c|c|c|c|c|c|}
\hline \multirow{3}{*}{ Population } & PEG $(\%)$ & $\begin{array}{c}\text { Total } \\
\text { protein } \\
(\mathrm{mg} / \mathrm{g} \mathrm{FW})\end{array}$ & $\begin{array}{c}\text { Proline } \\
(\mu \mathrm{mol} / \mathrm{g} \mathrm{FW})\end{array}$ & $\begin{array}{c}\text { CAT } \\
(\mu \mathrm{mol} / \mathrm{min} . \mathrm{mg} \\
\text { protein })\end{array}$ & $\begin{array}{c}\text { POX } \\
(\mu \mathrm{mol} / \mathrm{min} . \mathrm{mg} \\
\text { protein })\end{array}$ \\
\hline \multirow{3}{*}{ 'Ardestan' } & Control & $17.91^{\mathrm{d}}$ & $3.23^{\mathrm{d}}$ & $0.002^{\mathrm{d}}$ & $0.06^{\mathrm{c}}$ \\
\cline { 2 - 6 } & 5 & $18.91^{\mathrm{d}}$ & $6.14^{\mathrm{c}}$ & $0.004^{\mathrm{c}}$ & $0.11^{\mathrm{a}}$ \\
\cline { 2 - 6 } & 10 & $23.87^{\mathrm{c}}$ & $9.43^{\mathrm{b}}$ & $0.005^{\mathrm{bc}}$ & $0.09^{\mathrm{b}}$ \\
\cline { 2 - 6 } & Control & $13.07^{\mathrm{e}}$ & $7.13^{\mathrm{c}}$ & $0.003^{\mathrm{d}}$ & $0.06^{\mathrm{c}}$ \\
\cline { 2 - 6 } & 5 & $37.93^{\mathrm{b}}$ & $10.98^{\mathrm{ab}}$ & $0.006^{\mathrm{a}}$ & $0.07^{\mathrm{c}}$ \\
\cline { 2 - 6 } & 10 & $43.25^{\mathrm{a}}$ & $11.23^{\mathrm{a}}$ & $0.005^{\mathrm{ab}}$ & $0.06^{\mathrm{c}}$ \\
\hline
\end{tabular}

${ }^{*}$ Means in a column followed by the same letter do not differ significantly at $\mathrm{p}=0.05$

\section{Assessment of trigonelline content under drought and salinity stress}

Results shown in the table (7) indicated that the drought and salinity stress had remarkable effect in decreasing trigonelline content of callus in all treatments. Totally, trigonelline content in both populations were decreased by increasing the severity of drought and salinity stress. The highest value of the compound trigonelline reached $1.261 \mathrm{mg} / \mathrm{g}$ dry weight in control treatment of 'Borazjan' and decreased compared with the salinity and drought stress treatments. The lowest trigonelline content among treatments were observed in drought stress treatments were in $10 \%$ PEG which gave $0.007 \mathrm{mg} / \mathrm{g}$ dry weight in 'Ardestan' population. Comparing the trigonelline content between field grown papulations of fenugreek plant with callus Trigonelline content revealed that field grown plant had higher trigonelline content. High trigonelline content from fenugreek calli compared to the in vivo condition presented by Ahmad et al. (2000) using different explant. They were recorded Trigonelline content in different part of plant including stem $(0.21 \mathrm{mg} / \mathrm{g})$, leave $(0.45 \mathrm{mg} / \mathrm{g})$ and root $(0.29 \mathrm{mg} / \mathrm{g})$ at in vivo condition. Whereas, the amount of trigonelline in calli as recorded in stem $(0.61 \mathrm{mg} / \mathrm{g})$, leave $(0.3 \mathrm{mg} / \mathrm{g})$ and root $(0.21 \mathrm{mg} / \mathrm{g})$.

Variable effects of sodium choloride and osmolytes such as manitiol and PEG on callus growth and secondary metabolite such as trigonelline content have been reported by different researchers (Berglund, 1996; Hussain and Aghlan, 2011; Cho, 2011; Bashir and Alaf, 2016, Bitarafan, 2018) and must have related research reported the positive effects of different stress on Trigonelline content increase. Whereas, the amount of recorded trigonelline content in calli in our study was lower than their respective control. In the other hand both studied stresses had negative effect on Trigonelline content. It seems this differ in results back to the genetic difference and seed origin of both populations.

Berglund (1996) reported that nicotine amide and its related metabolites, especially trigonellin, work and act as a carrier of the plant in response to oxidative stress. The osmolytes accumulation such as glycine, betaine, proline, and trigonellin in cell is known to protect organisms against abiotic stresses via osmoregulation or osmoprotection. Tramontano and Zhou (1997) found two-fold changes in trigonelline levels after induction of salinity in Medicago sativa. Further research to compare the effect of trigonelline and other osmotic regulators on cell cycle parameters in cultured chickpea (Pisum sativum) root cells showed that $10^{-4}$ to $10^{-7} \mathrm{~mol} / \mathrm{l}$ trigonelline increased special molecules in the $\mathrm{G}_{2}$ phase; proline is ineffective while beta-glycine was slightly effect in the accumulation of these substances in the $G_{2}$ phase (Tramontano and Jouve, 1997). In the present study, it seems that callus was resistant to the stress condition by enhancing biochemical substance including proline, protein and related enzymes. But, trigoneline content were decreased under stress conditions compared to control. Investigation of soybean trigonline content in saline and water deficit stress conditions showed that trigonline content were increased in young plants and decreased in the reproductive stage (Minorsky, 2002). In the present study, it is also possible that high trigonelline content in the field plant may be due to the growth stage and low amount of the trigonalin content in callus culture may related to the subculture effect, as reported for diosegene (Jamshidi et al., 2014; Joanna et al., 2015) .Further investigation on trigonelline is needed. 
Table 7. Trigonelline content $(\mathrm{mg} / \mathrm{g})$ in calli obtained from 'Ardestan' and 'Borazjan' populations of fenugreek under salinity and drought stress

\begin{tabular}{|l|c|c|c|c|c|c|}
\hline \multirow{3}{*}{ Population } & \multicolumn{6}{|c|}{ Treatments } \\
\cline { 2 - 7 } & \multicolumn{2}{|c|}{ Culture condition } & \multicolumn{2}{|c|}{ PEG } & \multicolumn{2}{c|}{$\mathrm{NaCl}(\mathrm{mM})$} \\
\cline { 2 - 7 } & Field grown & Control & $5 \%$ & $10 \%$ & $70(\mathrm{mM})$ & $120(\mathrm{mM})$ \\
\hline 'Ardestan' & 0.852 & 0.313 & 0.014 & 0.007 & 0.068 & 0.018 \\
\hline 'Borazjan' & 0.494 & 1.261 & 0.809 & 0.806 & 0.494 & 0.394 \\
\hline
\end{tabular}

\section{Conclusions}

In vitro tissue culture could be an important means of improving crop tolerance and yield through genetic transformation as well as by induced soma clonal variation. Therefore, it is important to devise an efficient protocol of callus proliferation to start in vitro selection for salt and drought stress tolerance, and to broaden opportunities for genetic manipulation of fenugreek (Trigonella foenum-graecum) through tissue culture, including trying various population and explants type. The results of this study indicated that MS medium contain $2 \mathrm{mg} / \mathrm{l} 2,4-\mathrm{D}$ and $1 \mathrm{mg} / \mathrm{l} \mathrm{Kin} \mathrm{showed} \mathrm{a} \mathrm{good} \mathrm{callus} \mathrm{induction} \mathrm{and} \mathrm{growth} \mathrm{in} \mathrm{cotyledon} \mathrm{and}$ hypocotyl and apical bud explants. Both salt and drought stress resulted to decrease in callus growth and increase in protein, catalase, peroxidase and proline content in both populations. Also, trigoneline content in both populations under salt and drought stress were decreased in comparison with control treatment.

\section{Authors' Contributions}

GHA and LK - designed the experiments, interpreted the data, performed statistical analysis. GA wrote the paper; AT - discussed the results, gave technical support; LK, MH, and GHA - Discussed the results, contributed to manuscript review and editing; Data curation; Formal analysis; Investigation and Methodology. All authors read and approved the final manuscript.

\section{Acknowledgements}

The authors are grateful to Tissue, Culture and Biotechnology Laboratory technician of Persian Gulf University for their valuable technical assistance.

\section{Conflict of Interests}

The authors declare that there are no conflicts of interest related to this article.

\section{References}

Abeles FB, Biles CL (1991). Characterization of peroxidases in lignifying peach fruit endocarp. Plant Physiology 95(1):269-273. https://doi.org/10.1104/pp.95.1.269

Aebi H (1974). Methods of enzymatic analysis. Bergmeyer HU (Ed.). pp 673-677. https://doi.org/10.1016/B978-0-12-091302-2.50032-3

Anjum SA, Xie XY, Wang LC, Saleem MF, Man C, Lei W (2011). Morphological, physiological and biochemical responses of plants to drought stress. African Journal of Agricultural Research. 6(9):20262032. https://doi.org/10.5897/AJAR10.027 
Bates LS, Waldren RP, Teare ID (1973). Rapid determination of free proline for water stress studied. Plant and Soil 39(1):205-207. https://doi.org/10.1007/BF00018060

Berglund T, Kalbin G, Strid A, Rydstrom J, Ohlsson AB (1996). UV-B and oxidative stress induced increase in nicotinamide and trigonelline and inhibition of defensive metabolism induction by poly (ADP-ribose) polymerase inhibitor in plant tissue. FEBS Letters 380(1):188-193. https://doi.org/10.1016/0014-5793(96)00027-0

Bitarafan Z, Asghari H, Hasanloo T, Gholami A, Moradi F (2018). Biochar effect on seed trigonelline content of fenugreek (Trigonella foenum-graceum L.) ecotypes under deficit irrigation. Journal of Medicinal and Aromatic Plants 34(1):155-165. https://doi.org/10.22092/IJMAPR.2018.115556.2147

Bradford M (1976). A rapid and sensitive method for the quantitation of microgram quantities of protein utilizing the principle of protein-dye binding. Analytical Biochemistry 72:248-254. https://doi.org/10.1016/0003-2697(76)90527-3

Cho Y, Kodjoe E, Puppala N, Wood AJ (2011). Reduced trigonelline accumulation due to rhizobial activity improves grain yield in peanut (Arachis hypogaea L.). Acta Agriculturae Scandinavica, Section-Soil and Plant Sciences 61(5):395-403. https://doi.org/10.1080/09064710.2010.494614

Esam AH, Esam MA (2011). Effect of mannitol and sodium chloride on some total secondary metabolites of fenugreek calli cultured in vitro. Plant Tissue Culture \& Biotechnology 21(1):35-43. https://doi.org/10.3329/ptcb.v21i1.9561

Esmaeilzadeh B, Rezaeinodehi A (2014). Increased trigonelline production by salicylic acid in fenugreek (Trigonella foenum-graecum L.) cell culture. Journal of Cell and Tissue 5(2):165-172.

Farhadi H, Azizi M, Nemati H (2014). The effect of water deficit stress on morphological characteristics and yield components of eight fenugreek landraces (Trigonella foenum-graecum L.). Research Journal of Crop Science in Arid Area 1(1):1-19. https://doi.org/10.22034/CSRAR.01.01.10

Gurel S, Gurel E, Kaya Z (2011). Callus development and indirect shoot regeneration from seedling explants of sugar beet (Beta vulgaris L.) cultured in vitro. Turkish Journal of Botany 25:25-33.

Hajihashemi Sh, Rajabpour Sh (2017). The effect of paclobutrazol and gibberellin treatments on drought stress alleviation of Stevia rebaudiana callus. Journal of Plant Process and Function 6(21):1-14. (Persian)

Heng-Moss TM, Sarath G, Baxendale FP (2004). Characterization of oxidative enzyme changes in buffalo grasses challenged by Blissus occiduus. Journal of Economic Entomology 97:1086-1095. https://doi.org/10.1093/jee/97.3.1086

Hildebrand DF, Rodriguez JG, Brown GC (1986). Peroxidative responses of leaves in two soybean genotypes injured by two spotted spider mites (Acari: Tetranychidae). Journal of Economic Entomology 79:1459-1465. https://doi.org/10.1093/jee/79.6.1459

Hall JL, Flowers TJ (1973). The effect of salt on protein synthesis in the halophyte Suaeda maritima. Planta 110:361-368. https://doi.org/10.1007/BF00387064

Hayat Sh, Hayat Q, Alyemeni MN, Wani A, SH, Pichtel J, Ahmad A (2012). Role of proline under changing environments. Plant Signaling Behavior 7(11):1456-1466. https://doi.org/10.4161/psb.21949

Jamshidi S, Lahouti M, Ganjeali A (2014). Assessment of callus growth and bioproduction of diosgeninin callus culture of Trigonella foenum-graecum L. Bulletin of Environment, Pharmacology and Life Sciences 3:191-198.

Joanna C, Magdalena S, Mirosław T (2015). Optimization of in vitro culture conditions for accumulation of diosgenin by fenugreek. Journal of Medicinal Plants Studies 3(3):22-25

Khadiga G, Elaleem A, Ahmed MM, Eldin B, Saeed AE (2014). Study of the in vitro callus induction Trigonella foenumgraecum L. from cotyledons and hypocotyls explants supplemented with various plant hormones. International Journal of Current Microbiology and Applied Sciences 3(12):486-493.

Khawar KM, Gulbitti- Onarici S, Coecue S, Erisen S, Sancak C, Ozcan S (2004). In vitro crown galls induced by Agrobacterium tumefaciens strain A281 (pTiBo542) in Trigonella foenum-graecum. Biologia Plantarum 48(3):441-444. https://doi.org/10.1023/B:BIOP.0000041100.94688.2d

Kyani A, Niknam V (2015). Comparative responses of two Trigonella species to salinity and drought stresses in vitro. Progress in Biological Sciences 5(2):233-248. https://doi.org/10.22059/PBS.2015.56041

Layegh KH, Lahouti M (2011). Comparative study of the effect of drought stress on proline variations in Salvia leriifolia in soil and in vitro culture media. Journal of Biological Sciences 4(1):105-115.

Levitt J (2015). Water, radiation, salt, and other stresses. Elsevier 2(1):622. 
Mawahib EM, Lamia E, Mohammed S, Badereldin AS (2013). In vitro callus induction of fenugreek (Trigonella foenumgraecum L.) using different media with different auxins concentrations. Agriculture and Biology Journal of North America 4(3):243-251. https://doi.org/10.5251/abjna.2013.4.3.243.251

Mehrafarin A, Ghaderi A, Rezazadeh SH, Naghdi BH, Nourmohammadi G, Zand ES (2010). Bioengineering of important secondary metabolites and metabolic pathways in fenugreek (Trigonella foenumgraecu L.). Journal of Medicinal Plants 9(35):1-18.

Minorsky PV (2012). Trigonelline: a diverse regulator in plants. Plant Physiology 128(1):7 -8.

Naveen CP, Ruchi A, Sanjeev A (2014). Mannitol-induced drought stress on calli of Trigonella foenum-graecum L. var. RMt-303. Indian Journal of Experimental Biology 52:1128-1137.

Pandey R, Agarwal RM (1998). Water stress-induced change in proline contents and nitrate reductase activity in rice under light and dark condition. Physiology and Molecular Biology of Plants 4: 53-57.

Piri Kh, Nazarian F (2001). Plant tissue culture. Abu Ali Sina University Press, pp 352.

Rakmini M, Benedicate S, Vivanads DS (2004). Superoxid dismutase and catalase activities and their correlation with malondealdehyde in schizophrenic patients. Indian Journal of Clinical Biochemistry 19:114-118. https://doi.org/10.1007/BF02894268

Rezaian Sh, Lahouti M, Mahmoudzadeh H (2011). Evaluation of the effect of 2,4-D concentrations and light conditions on the rate of callus formation (Trigonella foenum-graecum L.) in vitro. Journal of Biological Sciences 3(3):107114.

Rongjie Z, Li W, Longxing W (2010). Determination of trigonelline in Trigonella foenum-graecum L. by hydrophilic interaction chromatography. Chinese Journal of Chromatography 4:379-382. https://doi.org/10.3724/SP.J.1123.2010.00379

Salma UK, Khatun F, Bhuiyan MJH, Yasmin S, Khan TH (2016). In vitro screening for drought tolerance of some chickpea varieties in Bangladesh. Progressive Agriculture 27(2):110-118. https://doi.org/10.3329/pa.v27i2.29319

Saneoka H, Moghaieb REA, Premachandra GS, Fujita K (2004). Nitrogen nutrition and water stress effects on cell membrane stability and leaf water relations in Agrostis palustris Huds. Environmental and Experimental Botany 52:131-138. https://doi.org/10.1016/j.envexpbot.2004.01.011

Sarahi NM, Moradi B (2011). The effect of salinity on protein content, pigments, sugars and phenolic compounds in tissue culture of several species of Iranian fenugreek. Journal of Sciences, Islamic Republic of Iran 36(2):53-59.

Saravanan S, Nadarajan N (2010). Effect of media supplements on in vitro response of sesame (Sesamum indicum L.) genotypes. Research Journal of Agriculture and Biological Sciences 1(1):98-100.

Serraj R, Sinclair TR (2002). Osmolyte accumulation: Can it really help increase crop yield under drought conditions. Plant, Cell and Environment 25(2):333-341. https://doi.org/10.1046/j.1365-3040.2002.00754.x

Shibli RA, Kushad M, Yousef GG, Lila M (2007). Physiological and biochemical responses of tomato micro shoots to induced salinity stress with associated ethylene accumulation. Plant Growth Regulation 51:159-169. https://doi.org/10.1007/s10725-006-9158-7

Soheilikhah Z, Karimi N, Ghasmpour H, Zebarjadi A (2013). Effects of saline and mannitol induced stress on some biochemical and physiological parameters of Arthamus tinctorius L. varieties callus cultures. Australian Journal of Crop Science 7(12):1866-1874.

Taha H, El-Bahr M, Seif-El-Nasr M (2009). In vitro studies on Egyptian Catharanthus roseus (L.) G. Don. IV: manipulation of some amino acids as precursors for enhanced of indole alkaloids production in suspension cultures. Australian Journal of Basic and Applied Sciences 3(4):3137-3144.

Tramontano WA, Jouve D (1997). Trigonelline accumulation in salt stressed legumes and the role of other osmoregulators as cell cycle control agents. Phytochemistry 44(6):1037-1040. https://doi.org/10.1016/S0031-9422(96)00715-7

Vaezi Z, Daneshvar M, Heidari M, ChehraziM (2015). Indirect regeneration plant fenugreek (Trigonella foenumgraecum L.), with the use of plant growth regulators in vitro. Bulletin of Environment, Pharmacology and Life Sciences 4(5):103-108.

Zhang J, Nguyen HT, Blum A (1999). Genetic analysis of osmotic adjust-ment in crop plants. Experimental Botany 50 (332):291-302. https://doi.org/10.1093/jxb/50.332.291

Zia A, Rezanejad F, Safarnejad A (2010). In vitro selection for $\mathrm{NaCl}$ tolerance in Thymus vulgaris L. Journal of Cell and Molecular Research 2(2):86-92. 
OPEN ACCESS

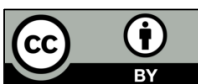

The journal offers free, immediate, and unrestricted access to peer-reviewed research and scholarly work. Users are allowed to read, download, copy, distribute, print, search, or link to the full texts of the articles, or use them for any other lawful purpose, without asking prior permission from the publisher or the author.

License - Articles published in Notulae Botanicae Horti Agrobotanici Cluj-Napoca are Open-Access, distributed under the terms and conditions of the Creative Commons Attribution (CC BY 4.0) License. (C) Articles by the authors; UASVM, Cluj-Napoca, Romania. The journal allows the author(s) to hold the copyright/to retain publishing rights without restriction. 